Please cite this article as:

Dell'Era C and Landoni P (2014).

Living Lab: A Methodology between User-Centred Design and Participatory Design.

Creativity and Innovation Management, Vol. 23, No. 2, Pp. 137-154.

(DOI: 10.1111/caim.12061) 


\section{LIVING LAB:}

\section{A METHODOLOGY BETWEEN USER-CENTRED DESIGN AND PARTICIPATORY DESIGN}

Claudio Dell'Era (corresponding author)

Politecnico di Milano, Department of Management, Economics and Industrial Engineering Piazza L. da Vinci 32 - 20133 Milano, Italy

E-mail: claudio.dellera@polimi.it

\section{Paolo Landoni}

Politecnico di Milano, Dipartimento di Ingegneria Gestionale

Piazza L. da Vinci 32 - 20133 Milano, Italy

E-mail: paolo.landoni@polimi.it

\section{Acknowledgments}

We acknowledge the research support provided by Carlo Coppola and Mattia Mrvosevic. The usual disclaimers apply. Financial support from the Lombardy Region fund "Dote Ricercatori e della Dote Ricerca Applicata per lo sviluppo del capitale umano nel sistema universitario lombardo" is also gratefully acknowledged. 


\title{
LIVING LAB: \\ A METHODOLOGY BETWEEN USER-CENTRED DESIGN AND PARTICIPATORY DESIGN
}

\begin{abstract}
Living Labs have received limited attention in the literature despite their diffusion throughout Europe and recent interest from policy makers. This limited attention is linked to the newness of the phenomenon, the high heterogeneity of cases and the consequent lack of definitions and acknowledged frameworks for scholarly analyses. In this work, we argue that the originality of the Living Lab phenomenon resides in the introduction of a new methodology. Using an analysis of the literature and case studies, we propose a new definition, position this methodology among other design methodologies and highlight its peculiarities. We underline the co-creative potentialities, the awareness of users and the real-life settings. Furthermore, our case-based research allows us to identify four different specifications for this methodology, and therefore four different types of Living Labs, based on the openness of the user involvement and the adopted platform technology.
\end{abstract}

\section{INTRODUCTION}

The advantages of user-centred design adoption have been demonstrated by scholarly studies (e.g., Vredenburg, Isensee and Righi 2002, Chayutsahakij and Poggenpohl 2002, Veryzer and Borja de Mozota 2005) and the success of major design firms such as IDEO (Kelley 2001) and Continuum (Lojacono and Zaccai 2004). Using this approach, users can be considered to be sources of innovation, and firms can identify unique insights by asking users about their needs or, even more effectively, observing them during the use of existing products and tracking their behaviour during consumption processes. Several different methods identify user needs and involve users in the innovation process. Two important methods are Applied Ethnography and Lead User Innovation. Applied Ethnography can be defined as the practice of observing users in the context of use (Sanders, 1992; Ball et al., 2000). Eric Von Hippel has investigated the crucial role of lead users in the innovation process, demonstrating that lead users can significantly contribute to the development of innovation beyond highlighting or demonstrating their needs (Von Hippel, 2001 and 2005). These interactions have been facilitated by recent developments in information and communication technologies. For instance crowdsourcing uses an open call to source tasks traditionally performed by specific individuals from an undefined large group of people or a community (e.g., Pisano and Verganti, 2008). More recently, the design research is evolving from a user-centred approach (with user as subject) to a participatory one (with user as partner). According to Sanders and Stappers (2008), co-creation at the early front end of the design development process can create positive, long-term consequences. Therefore, organisations and enterprises are looking for new methodologies to involve users in their innovation processes.

The Living Lab methodology can provide new perspectives in the passage from user-centred to participatory design. The literature regarding the Living Labs phenomenon is very limited to the point that there is a lack of a widely recognised definition (Kviselius and Andersson, 2009; Tang et al., 2012). Scholars and practitioners have provided many definitions of Living Labs (see Table 1), but the majority of these works on the subjects are working papers or selfpublished papers. We argue that these definitions have failed to highlight the original new 
product development approach implied by the Living Lab methodology. In fact, many definitions have focused on organisational characteristics of the managing entity or environmental characterisation. Both aspects are relevant, but neither fully illustrates the methodological peculiarities of Living Labs.

\begin{tabular}{|c|c|c|}
\hline$\#$ & Definition & Source \\
\hline 1 & $\begin{array}{l}\text { "Both a methodology for User Driven Innovation (UDI) and the organisations } \\
\text { that primarily use it" }\end{array}$ & $\begin{array}{l}\text { ENoLL } \\
\text { www.openlivinglabs.eu }\end{array}$ \\
\hline 2 & $\begin{array}{l}\text { "A user-driven open innovation ecosystem based on a business - citizens- } \\
\text { government partnership which enables users to take an active part in the } \\
\text { research, development and innovation process" }\end{array}$ & $\begin{array}{l}\text { European Commission } \\
\text { Information Society } \\
\text { and Media }\end{array}$ \\
\hline 3 & $\begin{array}{l}\text { "An organised set of methods and stakeholder, which focus on user } \\
\text { involvement, user-centric research methodology for sensing, prototyping and } \\
\text { validating solutions in evolving real life contexts" }\end{array}$ & $\begin{array}{l}\text { Vinnova } \\
\text { http://www.vinnova.se }\end{array}$ \\
\hline 4 & $\begin{array}{l}\text { "Consciously constructed social environments in which the uncontrollable } \\
\text { dynamics of everyday life are accepted as part of the innovation environment } \\
\text { which enables designers and users to co-produce new products and services" }\end{array}$ & $\begin{array}{l}\text { Frissen and van } \\
\text { Lieshout (2004) }\end{array}$ \\
\hline 5 & $\begin{array}{l}\text { "A user-centric research methodology for sensing, prototyping, validating and } \\
\text { refining complex solutions in multiple and evolving real life contexts" }\end{array}$ & Eriksson et al. (2005) \\
\hline 6 & $\begin{array}{l}\text { "Experimentation environment in which technology is given shape in real-life } \\
\text { contexts and in which (end) users are considered co-producers" }\end{array}$ & Ballon et al. (2005) \\
\hline 7 & $\begin{array}{l}\text { "Functional regions where stakeholders have formed a Public-Private- } \\
\text { Partnership (PPP) of firms, public agencies, universities, institutes and people } \\
\text { all collaborating for creation, prototyping, validating and testing of new } \\
\text { services, products and systems in real-life contexts. Such contexts are cities, } \\
\text { villages, rural areas and industrial plants" }\end{array}$ & $\begin{array}{l}\text { CoreLabs project } \\
(2007)\end{array}$ \\
\hline 8 & $\begin{array}{l}\text { "Systemic innovation approach in which all stakeholders in a product, service } \\
\text { or application participate directly in the development process" }\end{array}$ & Feurstein et al. (2008) \\
\hline 9 & $\begin{array}{l}\text { "Home-like environment by ambient intelligence and ubiquitous computing } \\
\text { technologies such as wireless and sensor technologies to sense, prototype and } \\
\text { validate complex ICT solutions" }\end{array}$ & $\begin{array}{l}\text { Ståhlbröst and } \\
\text { Bergvall-Kåreborn } \\
(2008)\end{array}$ \\
\hline 10 & $\begin{array}{l}\text { "A user-centric innovation milieu built on every-day practice and research, } \\
\text { with an approach that facilitates user influence in open and distributed } \\
\text { innovation processes engaging all relevant partners in real-life contexts, } \\
\text { aiming to create sustainable values" }\end{array}$ & $\begin{array}{l}\text { Bergvall-Kåreborn et } \\
\text { al. (2009) }\end{array}$ \\
\hline 11 & $\begin{array}{l}\text { "Open innovation environment in real-life settings in which user-driven } \\
\text { innovation is the co-creation process for new services, products and societal } \\
\text { infrastructures" }\end{array}$ & $\begin{array}{l}\text { Living Lab Handbook } \\
\text { (2010) }\end{array}$ \\
\hline 12 & $\begin{array}{l}\text { "Testing in a live environment with real end-users and in cooperation with } \\
\text { players from the entire value chain will help companies evaluate their services } \\
\text { and allow adjustments and corrections to be made well in advance of launch" }\end{array}$ & Kallai (2010) \\
\hline 13 & $\begin{array}{l}\text { "An R\&D concept which aims to create innovations in a multi-contextual, } \\
\text { real-world setting" }\end{array}$ & $\begin{array}{l}\text { Konsti-Laasko et al. } \\
\text { (2012) }\end{array}$ \\
\hline
\end{tabular}

Table 1: Living Lab Definitions

Despite the lack of a widely recognised definition (Kviselius and Andersson, 2009; Tang et al., 2012), we note that Living Labs share the following two primary elements: i) a real-life test and experimentation environment and ii) users who are aware that they are co-involved in the innovation process. For example, the pilot project "Malmö New Media Living Lab" was a small-scale Living Lab in which new media services and products were co-created with a particular focus on audience participation and user-generated content. Researchers, students, artists, professional new media producers and visitors to the media and performance centre INKONST were engaged in developing, experimenting with and evaluating new media formats, services and products. The method develops new media experiences and practices 
focused on engaging grassroot enthusiasts, building upon their needs and trying out concepts developed in a real setting.

Living Labs are an emerging and rapidly diffusing phenomenon, as demonstrated by the growth of the European Network of Living Labs (ENoLL), the main Living Lab association. ENoLL (www.openlivinglabs.eu), the international federation of Living Labs in Europe, recently opened its association to Living Labs worldwide. Despite their growing recognition and diffusion throughout society, the Living Labs literature remains scarce, and few contributions have analysed their original approach to product development. The reasons for this limited literature certainly include the currently fragmented and difficult to define nature of these experiences and limited data availability.

Scholars and practitioners have provided many definitions of Living Labs (see Table 1), but have failed to highlight the original new product development approach implied by the Living Lab methodology. As highlighted by the literature many different experiences co-exist in the Living Labs, but they are all united by a focus on a new way to manage the new product development process. We acknowledge that Living Labs may often require ad hoc organisations and structures, and we additionally acknowledge the importance of the Living Lab's environment. However, we consider a focus on the methodology to be more useful. In certain cases, a formal organisation was not established, and a temporary partnership assumed managerial responsibility of the project. In many cases, the project's environmental setting place is not easy to define (e.g., entire cities or even regions). We thus define the Living Lab methodology as follows:

A Living Lab is a design research methodology aimed at co-creating innovation through the involvement of aware users in a real-life setting.

This definition shares two main elements with the real-life experimentation environment and the involvement of users in the co-creation, concepts previously defined in the literature. The proposed definition is aligned with interpretations proposed by Eriksson et al. (2005) and Schuurman, et al. (2012) who describe Living Labs as a user-centric research methodology to sense, prototype, validate and refine complex solutions in multiple and evolving real life contexts. Living Lab is an emerging Public Private Partnership (PPP) concept in which firms, public authorities and citizens work together to create, prototype, validate and test new services, businesses, markets and technologies in real-life contexts, such as cities, city regions, rural areas and collaborative virtual networks between public and private players.

Using literature and case study analyses of Living Labs in Europe, this paper aims to i) define and position the Living Lab methodology, clarifying its peculiarities and highlighting the typologies of user needs that the method allows to explore and ii) introduce a model that can support managers in the adoption of the appropriate Living Lab methodology. The paper is organised as follows. The next section introduces the literature background focusing on the user-centred and participatory design methodologies. The following section introduce the methodology and the collected data; then the results are presented and discussed. The paper concludes by highlighting study limitations and avenues for further research.

\section{LITERATURE BACKGROUND}

The recent literature on innovation and design management has made significant efforts to investigate a specific approach usually referred to as user-centred design (see for example Vredenburg et al., 2002; Chayutsahakij and Poggenpohl, 2002; Veryzer and Borja de Mozota, 2005). Several scholars claim that design research is progressively moving from a user- 
centred to a participatory approach (Schuler and Namioka, 1993; Muller and Kuhn, 1993; Sanders 2002 and 2006). To position the Living Lab methodology among the other methodologies, the following paragraphs summarise the main literature contributions about the design research methodologies based on user-centred and participatory paradigms. Specifically we leverage on the map about research design methodologies proposed by Sanders (2006) (see Figure 1).

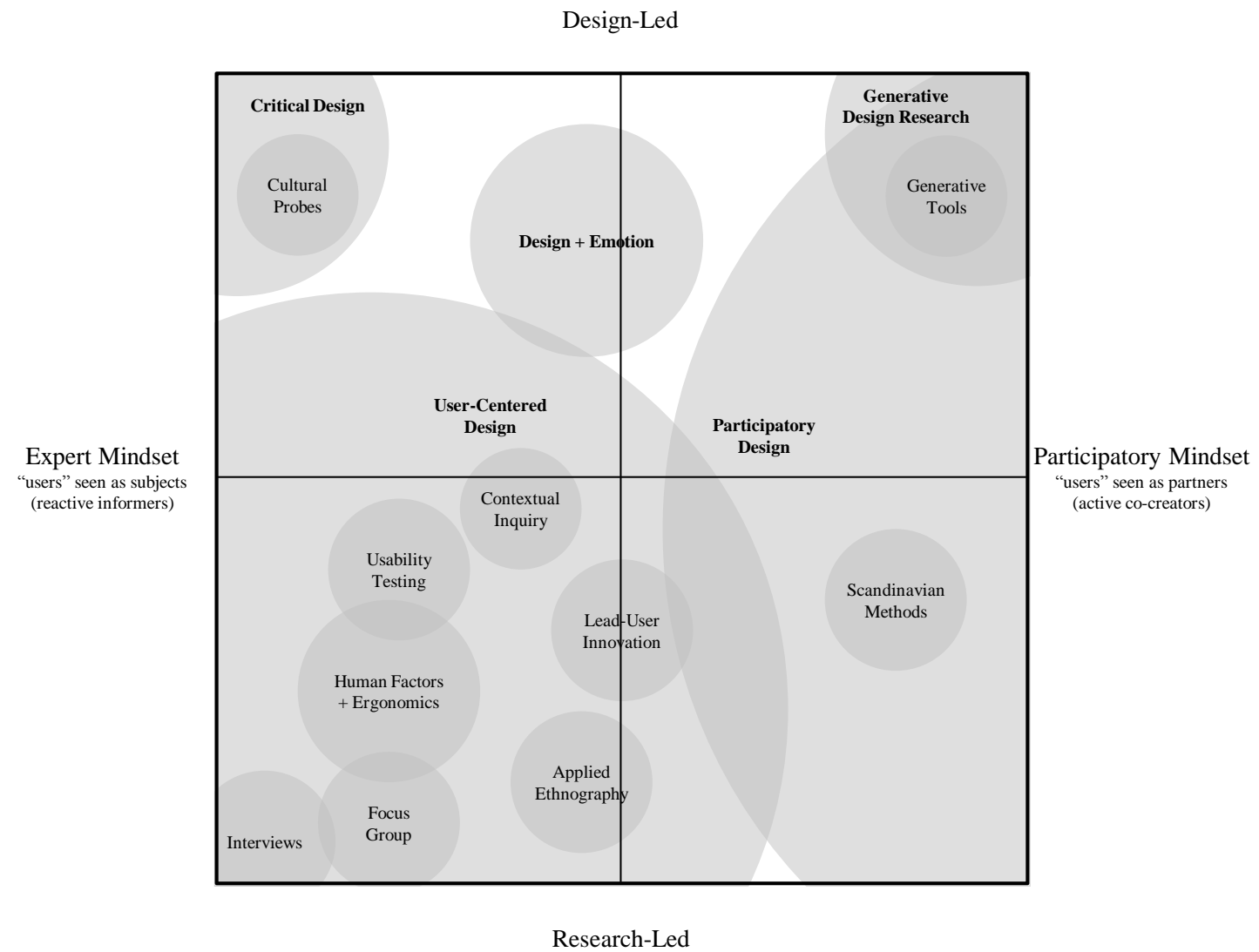

Figure 1: Map of Design Research Methodologies (adapted from Sanders, 2006)

In this map, the vertical dimension describes the impetus of the design research approaches. The top half (i.e., design-led) contains design research methodologies that have been introduced into practice from a design perspective. The lower half (i.e., research-led) contains design research methodologies that have been introduced into practice from a research perspective. The horizontal dimension describes the mindsets of those who practice and teach design research. The left side exemplifies the expert mindset. At the bottom of the left side, researchers talk about the people that they do research on as subjects, or informers or users. The people are asked questions and/or requested to respond to certain stimuli and/or observed. At the top of the left side, the designer is the expert who creates things to probe or provoke response from the people who are often referred to as the audience. The right side exemplifies the participatory mindset. On this side, the researchers or designers invite the people who will benefit from design into the design process as partners. In the following paragraphs we focus on the "research-led" methodologies mapped by Sanders (2006) because of their proximity with the Living Lab methodology. Finally we summarize the capability of each design research methodology to investigate specific categories of user needs.

\section{User-centred design}


The success enjoyed by major design firms such as IDEO (Kelley 2001) and Continuum (Lojacono and Zaccai 2004) have demonstrated the advantages of a user-centred design. This methodology considers users to be sources of innovation, and firms can identify unique insights and develop innovations by asking about user needs or, more effectively, by observing users during the use of existing products and tracking user behaviour during consumption processes. The analysis of several cases that adopted a user-centred design approach has enhanced or enabled the development of new interpretations of design as an organisational process. This type of approach abandons the classic and common interpretation of design as style and uses a deeper and more valuable interpretation of design as an organisational process. Based on this new interpretation, the recent literature has made several contributions identifying tools and models that support the application of a usercentred design approach (Patnaik and Becker, 1999; Sutton, 2001; Kumar and Whitney, 2003; Rosenthal and Capper, 2006). The discussion of theoretical references related to the classification of needs is particularly useful for describing the methodologies primarily used in the analysis of user needs. The basic classification of needs as explicit and latent depends on the degree to which needs are clear and evident to the subject. Obviously, the more explicit need is easier to satisfy, and the attempt to understand and satisfy irrational feelings that are not explicit may be particularly arduous. The category of needs that a company wants to analyse has an obvious effect on choosing the appropriate investigational method.

\section{Questionnaires and Interviews}

The methods traditionally used to identify customer needs presuppose that the customer knows best the characteristics that he or she desires to implement in a product; the tools used in this context include questionnaires and interviews with the intention of inducing customer communication of his or her own needs. The principal problem of this method is that the basic assumption is not completely exact, and it is only applicable to explicit needs. However, the customer often does not know his or her own needs, much less the needs of others or the needs that he or she may manifest in the future. Dahan and Hauser (2001) claim that scarce knowledge about a subject's own needs is primarily evident during the initial phases of new product development. In the case of radical innovations, the relationship and the interaction between customer and product change completely; consequently, the customer rarely recognises the conceptual schemes necessary to interpret the innovation. Another underlying problem associated with this method is the researcher's interviews and questionnaires may influence the collected answers; questions may be too intrusive, irritate the customer and lead to reluctant collaboration and encourage fake answers that compromise the results of the analysis.

\section{Focus Group}

The focus group represents a primarily qualitative and contemplative research method compared with questionnaires and interviews that the firm uses to consider what the customer reports to other participants and directly expresses to the firm. The participants in a focus group must constitute a representative sample of customers. The participants are invited to the company's offices and encouraged to discuss specific problems connected to products that the company wants to develop. In some focus groups, it is possible to observe the interaction between the participants and a prototype of the product with the purpose of analysing user behaviour. As underlined by Dahan and Hauser (2001), focus groups are subject to the social norms of the group and do not allow identification of certain needs that the customer prefers not to explicitly reveal in the presence of others. Thus, it is possible that some subject evaluations are conditioned by other opinions and expected opinions. 


\section{Human factors + Ergonomics}

Human factors and ergonomics is a multidisciplinary field incorporating contributions from psychology, engineering, biomechanics, mechanobiology, industrial design, graphic design, statistics, operations research and anthropometry. In essence it is the study of designing equipment and devices that fit the human body and its cognitive abilities. Specifically it concerns the study of how humans behave physically and psychologically in relation to particular environments, products, or services (which borrows from physiology, psychology and engineering). Human factors and ergonomics is employed to fulfill the goals of health and safety and productivity. It is relevant in the design of such things as safe furniture and easy-to-use interfaces to machines and equipment. Proper ergonomic design is necessary to prevent repetitive strain injuries and other musculoskeletal disorders, which can develop over time and can lead to long-term disability. To assess the fit between a person and the used technology, human factors specialists or ergonomists consider the job (activity) being done and the demands on the user; the equipment used (its size, shape, and how appropriate it is for the task), and the information used (how it is presented, accessed, and changed).

\section{Usability testing}

Usability testing is a technique used in user-centered interaction design to evaluate a product by testing it on users. This can be seen as an irreplaceable usability practice, since it gives direct input on how real users use the system. This is in contrast with usability inspection methods where experts use different methods to evaluate a user interface without involving users. Usability testing focuses on measuring a human-made product's capacity to meet its intended purpose. Examples of products that commonly benefit from usability testing are foods, consumer products, web sites or web applications, computer interfaces, documents, and devices. Usability testing measures the usability, or ease of use, of a specific object or set of objects, whereas general human-computer interaction studies attempt to formulate universal principles.

\section{Contextual inquiry}

Contextual inquiry is a user-centered design research method. A contextual inquiry interview is usually structured as an approximately two-hour, one-on-one interaction in which the researcher watches the user do their normal activities and discusses what they see with the user. It calls for one-on-one discussion sessions wherein users' daily routines or processes are discovered so that a product or website can be best designed to either work with the processes or help shorten or eliminate them altogether. Contextual inquiry comprises preparation, evaluation, analysis, and design phases.

\section{Applied Ethnography}

Ethnography is a research method borrowed and adapted from cultural anthropology; the basic assumption is that the customer is often not aware of certain aspects of his interaction with the product and is unable to express some of his or her needs related to the product. Therefore, Applied Ethnography consists of the observation of relationships between different actors in a natural context to gather the meaning attributed to the phenomenon and different points of view. The essential conditions that apply to this method indicate that the researcher must "immerse" himself or herself in the context and dedicate substantial time to the observation. An Applied Ethnography researcher is required to have a great deal of resources to obtain results strictly connected to the specific context. In ethnographic research, it is usually not possible to clearly identify and separate the object of the observation and the researcher because the output of the analysis is typically a joint production of the interaction between the two subjects. Applied Ethnography, or direct observation of consumer 
behaviours, does not explicitly underline or identify consumer needs. Instead, Applied Ethnography identifies the symptoms of unexpressed needs, such as frustration and confusion, fear and anxiety, lost time, wrong or unexpected use of the product, dangerous situations, product alterations, impossibility of use by certain consumers, interactions with the social and personal environment of the consumer or intangible product attributes (Burns et al., 1999; Kotler and Scott, 1999). The objective of ethnographic research is to analyse the actor's point of view and relationship with the context and understand the actor's vision of the world through a process of co-evolution. Ethnography means to learn from people rather than to study people (Spradley, 1979). The use of multimedia tools, such as recorders, video cameras and cameras, has notably facilitated this type of study and memorialises the datagathering process for later interpretation; the subsequent passage from data to knowledge can occur away from the object of the observation. The application of Applied Ethnography is enabled by the researcher affiliation with the socio-cultural context of the consumer. The researcher tries to harness, collect and memorialise the objects of the investigation, customer feelings and customer needs.

\section{Lead User Innovation}

Lead user innovation foresees the observation of particularly resourceful consumers that have autonomously developed "ad hoc" solutions to better satisfy their needs stemming from a certain degree of dissatisfaction with a product. Lead users differ from opinion leaders by determining functional and semantic changes to traditional products at a functional level and proposing previously unknown market solutions. Lead users directly interact with a product used daily. The literature proposes the following three categories of lead users (Thomke and Nimgade, 1999):

- Lead users in the target application - This group may include lead users who have actually experimented with developing prototypes;

- Lead users in analogous markets - This group may include lead users from other markets and underlie a sort of innovation osmosis from one industry to another. For instance, a health care firm interested in antibacterial control products for humans might actually find a lead user from the veterinarian sciences; and

- Lead user involved in more complex realities - This group may include lead users who use their knowledge to solve problems that are not directly connected to their area of competence. For instance, a refrigeration manufacturing firm may find lead users from the supercomputer industry because cooling technology plays an important role in computer operation.

Naturally, lead users are unknown people, for whom the company must encounter to access lead user knowledge and innovativeness. Von Hippel (1986) underscores the great difficulty of identifying a person with the aforementioned characteristics; he or she often realises personal solutions that cannot be diffused on the market. However, this research methodology offers numerous advantages. In addition to allowing the company to acquire articulated and reliable information about consumer needs, this method obtains information about desired characteristics and performance during the first phases of new product development. This method discovers potential problems before the market launch of the product and offers the company the possibility to proactively remedy a problem in the market.

\section{Participatory design}

Participatory design is an approach to design that attempts to actively involve all stakeholders (e.g. employees, partners, customers, citizens, end users) in the design process to help ensure that the product designed meets their needs and is usable. In participatory design participants are invited to cooperate with designers, researchers and developers during an innovation 
process. Potentially, they participate during several stages of this process: they participate during the initial exploration and problem definition both to help define the problem and to focus ideas for solution, and they participate during development to help evaluate proposed solutions. Sanders (2006) notes that participatory design attempts to involve future "users", to the extent that is possible, throughout the design development process. Participatory approaches have been recently proposed in many disciplines and studies such as the business community and policy initiatives (e.g., Tseng and Piller, 2003; Prahalad and Ramaswamy, 2004; Roveda et al., 2007). Participatory design, which is used to engage actual users in design activities, represents an example of a research method developed to support design work during concept generation and development phases. This type of approach is particularly diffused in computer science, where participatory design is defined as a set of theories, practices and studies related to end-users as full participants in software and hardware development, products and activities (Greenbaum and Kyng, 1991; Muller and Kuhn, 1993; Schuler and Namioka, 1993).

\section{Scandinavian Methods}

A key characteristic of participatory design is the use of physical artefacts as thinking tools throughout the process. This process is a key characteristic of the various participatory design practices emanating from the Scandinavian research-led tradition (e.g., Greenbaum and Kyng, 1991). As highlighted by Sanders (2006), users in participatory design serve as "expert[s] of their experiences" on the design team (Sleeswijk Visser et al., 2005), but "they must be given appropriate tools for expressing themselves".

\section{Design research methodologies and Users' needs}

The recent literature on new product development processes attempts to describe the interconnections between user needs and context of use as paradigm shift from "design for users" to "design with users" (Sanders, 2002). During the early 1980s, many designers, sociologists and anthropologists collaborated on a user needs analysis, but this type of approach soon presented limitations. This approach did not reach areas connected to emotion, memory or actual and ideal experiences. With this goal in mind, the philosophy of triangulation arose to address and analyse the three following different degrees of consumer knowledge (Sawhney et al., 2003): what people say; what people do; and what people make. Explicit needs can be identified by listening to what the customer says, while keeping in mind that the customer reveals only what he or she wants. Consequently, the customer determines the developmental direction of the analysis. However, analysing what the customer does and uses may be insufficient because this approach only notices observable needs and skips the unexplored area related to what the customer knows, feels and dreams (Sanders, 2002). The investigation of customer knowledge and convictions reveals some indications about their perception of reality and a variety of experiences. In addition, comprehension of the customer's feelings and sentiments may increase empathy with the analysed subject and underlying tacit knowledge. Customer dreams indicate how he or she would like the future to be. However, gathering such information necessarily and actively involves the studied subject in the development process and must allow the researcher to observe the type of solutions that he/she proposed without knowing the originating need. For example, the paradigm of the Experience Design (Sanders, 2001) focuses on the creation of a customer experience, and the emotional aspect of the product interaction becomes the fulcrum of the entire project.

Traditional marketing function analyses aim to identify explicit needs (what people say), while typical designer observations of contexts of use intend to identify what the customers do with the products (what people do and what people make). Anthropologists primarily 
develop analyses about the category what people make by using tools such as the collage, narration and construction of metaphors with ZMET (Sanders, 2001). The three categories of needs may be reinterpreted under the temporal horizon (Sanders, 2001), such that what people do underlines the actual situation, what people say reveals the past and the immediate future and what people make stimulates the researcher to investigate the remote past (memory) and the most distant future (dreams) (see Figure 2).

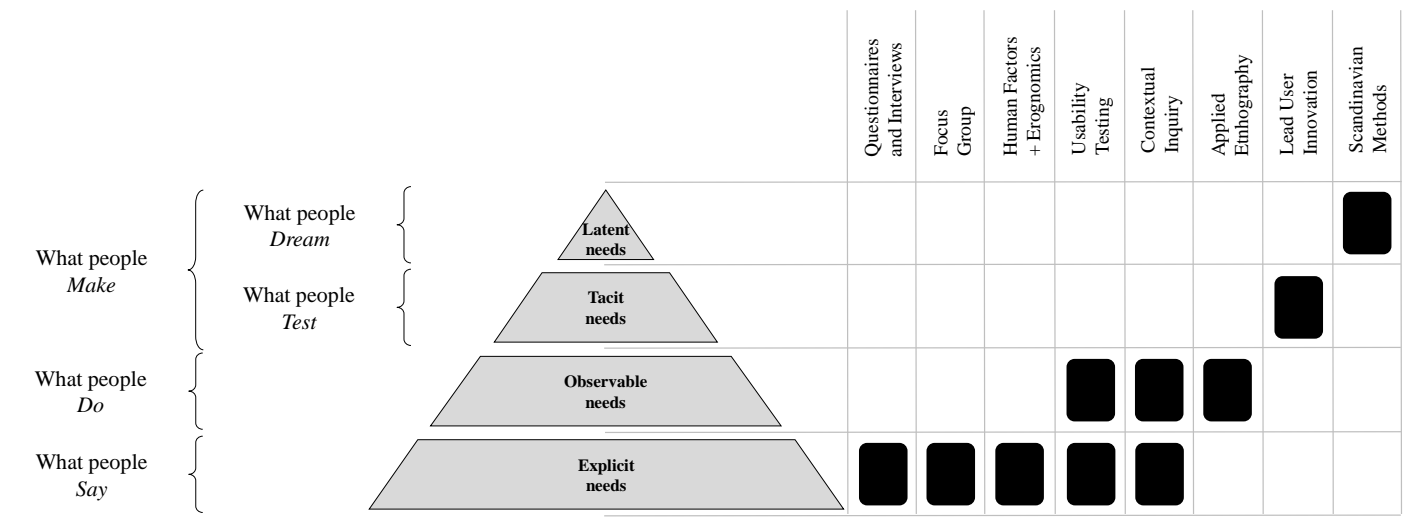

Figure 2: Design research methodologies and User needs (adapted from Sanders, 2002)

\section{RESEARCH METHODOLOGY}

Living Labs are an emerging, rapidly diffusing phenomenon as highlighted by the growth of its primary trade association, the European Network of Living Labs (ENoLL) (www.openlivinglabs.eu). ENoLL is the international federation of Living Labs in Europe, which recently expanded to include Living Labs worldwide. Founded in November 2006 under the auspices of the Finnish European Presidency, the network has grown in "waves". Five Waves have been launched to date, resulting in 274 accepted Living Labs. The ENoLL international non-profit association, which is the legal representative entity of the network, is headquartered in Brussels and acts as a representative and facilitating body. Despite the growing diffusion in the marketplace and recognition of Living Labs, the literature on Living Labs remains scarce, and few contributions have analysed this original approach to innovation.

We have adopted the case-study methodology approach. We consider this method properly suited to the exploratory nature of this research because the methodology allows us to discover those variables that are critical to better understand the problem and explore the phenomenon in its complexity. We analysed 14 case studies (see Table 2) that are exploratory, retrospective, multiple in nature and literally replicated (Eisenhardt and Graebner, 2007; Yin, 1984). The 14 case studies were selected according to the following process. First, a preliminary list of potential targets for the research was created by screening different sources of information, similar to the process described by Chesbrough and Crowther (2006). Three main sources of information taken into account include:

- Existing literature on the topic (Bergvall-Kåreborn et al., 2009; Eriksson et al., 2005; Feurstein et al., 2008; Kallai, 2010);

- Web searches to identify existing Living Labs;

- List provided by ENoLL. Our study has been facilitated by the existence of ENoLL. As previously mentioned, 5 Waves have been launched to date, resulting in 274 accepted 
Living Labs. We have focused on the first 2 Waves to select "mature" case studies and present a representative configuration.

In particular, this process allowed us to identify a list of 70 Living Labs (51 belong to the 1st and 2 nd waves organised by ENoLL, and 19 were identified by ad-hoc web searching). To identify the cases that are most suitable for the objectives of the present research, additional information on the 70 Living Labs were collected by looking at their website and publicly available information. The final sample of 14 Living Labs has been identified according to literal replication logic (Yin, 1984) and represents $20 \%$ of the initial set of Living Labs. We took the following criteria into account:

- We focused our attention on Living Labs with an easily observable innovation process (Eisenhardt and Graebner, 2007) and Living Labs that do not bundle the Living Lab service with additional consultancy services;

- We favoured heterogeneity in geographical localisation.

The data were collected by secondary resources triangulating different sources: Living Lab website, ENoLL website that provides a technical sheet about each member, literature, reports and press articles. The data analysis was based on a synthetic datasheet showing the following data for each Living Lab: history, governance, partners, user involvement and adopted technologies. Each case was analysed by two researchers and a research assistant. The next step was the construction of a data matrix (cases / dimensions) as recommended by Miles and Huberman (1994). The datasheets and the matrix (across cases) were analysed iteratively and separately by the authors. We found regularities and patterns across the cases. 


\begin{tabular}{|c|c|c|c|c|}
\hline \# & Living Lab & Country & Source & Brief description \\
\hline 1 & $\begin{array}{l}\text { Mobile City } \\
\text { Bregenz }\end{array}$ & Austria & $\begin{array}{l}\text { ENoLL (1st and } \\
\text { 2nd waves) }\end{array}$ & $\begin{array}{l}\text { Mobile City Bregenz offers mobile broadband infrastructure to support the development and the validation of new innovative services for citizens. } \\
\text { [www.openlivinglabs.eu/livinglab/mobile-city-bregenz] }\end{array}$ \\
\hline 2 & $\begin{array}{l}\text { Living Lab } \\
\text { Vorarlberg }\end{array}$ & Austria & Web searching & $\begin{array}{l}\text { Living Lab Vorarlberg facilitates innovation processes for the LL stakeholders by providing methods \& tools and ICT infrastructure for real-life } \\
\text { experiments with end-users. } \\
\text { [www.livinglab-vorarlberg.at/cms] }\end{array}$ \\
\hline 3 & IBBT-iLab.o & Belgium & $\begin{array}{l}\text { ENoLL (1st and } \\
\text { 2nd waves) }\end{array}$ & $\begin{array}{l}\text { The concept of IBBT City is to explore and achieve policy and business goals related to ICT innovation using an iterative model of stakeholder co- } \\
\text { design. This LL was established as a nucleus for open innovation activities and as a repository of relevant knowledge and expertise. } \\
\text { [www.openlivinglabs.eu/livinglab/ibbt-ilabo] }\end{array}$ \\
\hline 4 & $\begin{array}{l}\text { Turku } \\
\text { Archipelago } \\
\text { LL }\end{array}$ & Finland & $\begin{array}{l}\text { ENoLL (1st and } \\
\text { 2nd waves) }\end{array}$ & $\begin{array}{l}\text { Turku Archipelago LL seeks to diminish the disadvantage of isolated areas and provide full connectivity by means of collaboration, linking stakeholders } \\
\text { to provide services and share functionalities. It has installed mobile direct sales services and an e-democracy toolbox. } \\
\text { [www.openlivinglabs.eu/livinglab/turku-archipelago-ll] }\end{array}$ \\
\hline 5 & Arabianranta & Finland & $\begin{array}{l}\text { ENoLL }(1 \mathrm{st} \text { and } \\
\text { 2nd waves }\end{array}$ & $\begin{array}{l}\text { Arabianranta is a user-centric LL based on its social innovation potential for local civic, public and business activities in the creation and development of } \\
\text { services and products tailored to the needs of local community. } \\
\text { [www.arabianranta.fi] }\end{array}$ \\
\hline 6 & $\begin{array}{l}\text { Frascati Living } \\
\text { Lab }\end{array}$ & Italy & $\begin{array}{l}\text { ENoLL (1st and } \\
\text { 2nd waves) }\end{array}$ & $\begin{array}{l}\text { The main objective of this Living Lab is to develop, experiment and exploit innovation in real life scenarios involving incubation processes, traditional } \\
\text { rural applications as environments, agriculture (wine management) and tourism. A cooperation is set up to support the e-professionals' community. } \\
\text { [www.openlivinglabs.eu/livinglab/frascati-living-lab] }\end{array}$ \\
\hline 7 & Mobile Pass & Italy & Web searching & $\begin{array}{l}\text { With Mobile Pass users can buy a subscription from a mobile phone and travel using the public transportation service (e.g.. metro) paying the ticket with } \\
\text { the phone. } \\
\text { [www.atm.it/it/mobilepass/Pagine/default.aspx] }\end{array}$ \\
\hline 8 & CASST Centre & Ireland & Web searching & $\begin{array}{l}\text { The centre is a nationally unrivalled mobile communications test facility which can provide a " } 3 \mathrm{G} \& \text { Beyond" test bed for real and rapid development, } \\
\text { prototyping, interoperability, conformance testing and validation of wireless and mobile research. } \\
\text { [No longer available] }\end{array}$ \\
\hline 9 & Kenniswijk & Netherlands & Web searching & $\begin{array}{l}\text { Kenniswijk is a national project that is undertaken by a small professional organisation with a similar name, Kenniswijk. The intention was to create a } \\
\text { 'living' experimental environment in which consumers have access to innovative products and services in the area of computers, (mobile) communication } \\
\text { and the internet (broadband access). } \\
\text { [No longer available] }\end{array}$ \\
\hline 10 & $\begin{array}{l}\text { Rener Living } \\
\text { Lab }\end{array}$ & Portugal & $\begin{array}{l}\text { ENoLL (1st and } \\
\text { 2nd waves) }\end{array}$ & $\begin{array}{l}\text { Rener is a Living Lab focused in the energy sector, with particular attention to mobility. The main offered service is mobile-car sharing. } \\
\text { [www.openlivinglabs.eu/livinglab/rener-living-lab] }\end{array}$ \\
\hline 11 & Cantabria & Spain & Web searching & $\begin{array}{l}\text { The Cantabria main objective is to promote and deploy ICT in the local environment and to encourage stakeholders to participate in ICT projects. The } \\
\text { most important projects are related to e-health, e-government and e-administration. } \\
\text { [No longer available] }\end{array}$ \\
\hline 12 & Cudillero & Spain & $\begin{array}{l}\text { ENoLL (1st and } \\
\text { 2nd waves) }\end{array}$ & $\begin{array}{l}\text { Cudillero was born to offer technical support and services to fishermen to facilitate the daily work in a collaborative environment supported by an } \\
\text { integrated services platform. } \\
\text { [www.c-rural.eu/Cudillero_RuralLivingLab] }\end{array}$ \\
\hline 13 & $\begin{array}{l}\text { I2CAT } \\
\text { Catalonia }\end{array}$ & Spain & $\begin{array}{l}\text { ENoLL (1st and } \\
\text { 2nd waves) }\end{array}$ & $\begin{array}{l}\text { I2CAT has the capacity of managing and supporting large ITC projects and access to high tech infrastructure like Internet2 Network of advanced media, } \\
\text { grid and mobile services . } \\
\text { [www.openlivinglabs.eu/livinglab/i2cat-catalonia-digital-lab] }\end{array}$ \\
\hline 14 & Testbed Botnia & Sweden & $\begin{array}{l}\text { ENoLL (1st and } \\
\text { 2nd waves) }\end{array}$ & $\begin{array}{l}\text { Testbed Botnia offers innovative ICT services in Sweden. The main services are bus-timetables for the mobile phone, pharmacy services in the mobile } \\
\text { phone, mobile marketing, sporting arena services, and tourist info services. } \\
\text { [www.testplats.com] }\end{array}$ \\
\hline
\end{tabular}

Table 2: Living Lab case studies 


\section{EMPIRICAL RESULTS AND DISCUSSION}

The results regarding the two objectives of the paper are reported in this section. In particular, we i) clarify the peculiarities of the Living Lab methodology and ii) introduce a model to support manager adoption of the appropriate Living Lab methodology.

\section{Peculiarities of the Living Lab methodology}

The definition proposed in the "Research objectives and framework" section emphasises that users become aware of their involvement in the co-creation when they are invited to participate and does not specify the nature of the users. On the one hand, the users are involved and aware of the process, as opposed to users studied by Applied Ethnography. On the other hand, the users are not special in terms of skills or knowledge of the technologies as during lead user innovation. Errore. L'origine riferimento non è stata trovata. represents the partial overlapping and differences of these three methodologies on the map previously introduced (see Errore. L'origine riferimento non è stata trovata.). In particular, this positioning allows us to show that i) the context of use in the Living Lab methodology significantly affects the user's needs similar to Applied Ethnography, ii) users in the Living Lab methodology actively contribute to the innovation process, like the users in the lead user methodology, and iii) the co-creating activity of the Living Lab methodology usually supported by physical artefacts is aligned with participatory design approaches, specifically the Scandinavian Methods.

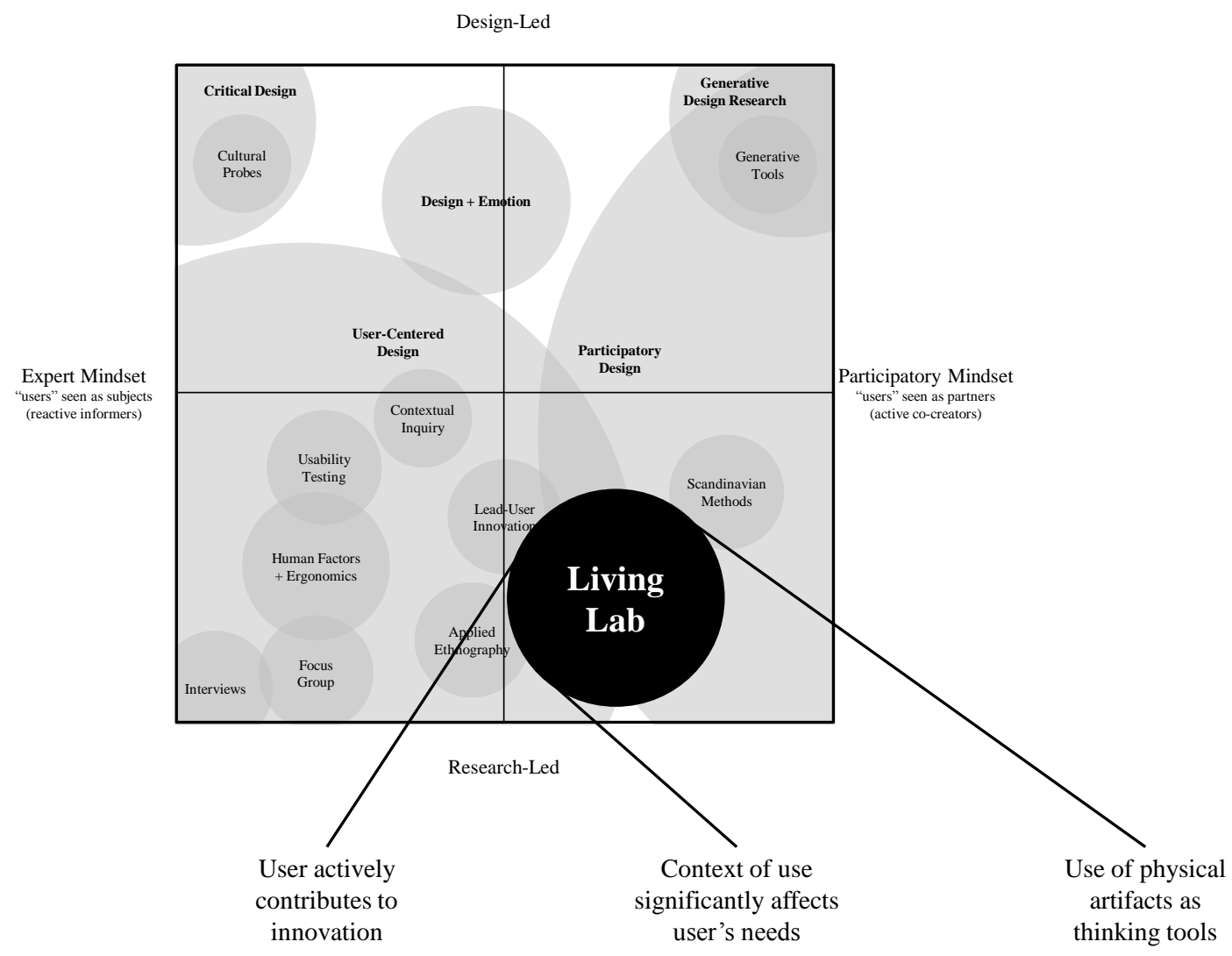

Figure 3: Positioning of the Living Lab methodology in the Design research methodologies described by Sanders, 2006. 
Design research methodologies suggest different interpretations of user and designer involvement. The users' needs explore by the different methodologies (including the Living Lab methodology) are summarized in Figure 5 and briefly presented in the following. Methodologies based on the analysis of questionnaires, interviews, focus groups and human factors aim at framing the innovation problem looking at users as direct interlocutors (designer role: framing). For this reason these design methodologies allow to analyze the explicit needs (see Figure 4). As emphasised by Sanders (2002), usability testing, contextual inquiry and especially applied ethnography are particularly powerful to investigate observable needs. The user plays a passive role, while the designer use the observations to interpret users' behaviours and attitudes (designer role: interpreting). Lead User Innovation enables the identification of tacit needs (Sanders, 2002). According to this design research methodology the user leverages on his deep knowledge and skills to proactively propose a potential solution while the designer has to translate it in a robust solution that can address the market needs (designer role: translating). As argued by Sanders (2002), Scandinavian Methods (Participatory Design) allow the investigation of latent needs. The responsibility for creation is shared between users and designers, resulting in a fully co-creative process led by the designer in controlled and temporary settings (designer role: leadership in co-creation).

The Living Lab methodology allows an exploration of different categories of users' needs, ranging from observable needs (similar to Applied Ethnography), to tacit needs (similar to Lead User Innovation) and latent needs (similar to the Scandinavian method). In the Living Lab methodology, as in the Scandinavian Methods, the shared responsibility for creation results in a co-creative process. However, the role of the context is crucial. The designer does not interact directly with the users and leaves the users free to interact with the environment (designer role: context design and leadership in co-creation). For example, the activities and expertise of Living Lab Vorarlberg are focused on the following domains: Mobile and wireless (web) applications and services, (mobile) City services \& applications, locationbased and context aware services and E-Health applications and services. Living Lab Vorarlberg not only facilitates living lab research in these domains but also plays an active role in conducting research. The research performed by Living Lab Vorarlberg is threefold: user oriented research with a qualitative approach, business modelling and policy research. Living Lab Vorarlberg uses a permanent living lab, which comprises the university campus. In terms of context, this living lab covers a geographic area of 1 square $\mathrm{km}$ and a population of 11,000 users. The approach adopted by the Living Lab is primarily based on qualitative techniques. Arabianranta serves as a home for 10,000 people, a workplace for 5,000 and a campus for 6,000 students and professionals. The residential district of Arabianranta is heterogenic, and experimentation with different types of housing has been favoured from the beginning of the district. Examples include modern loft buildings, city villas, Plus Koti (Plus Home) concept and homes for groups with special needs, such as Loppukiri (community housing for active elderly people), Käpytikka (residence for mentally disabled juvenile) and MS-Talo (MS House) (for people with MS). The Arabianranta district has formed a "participative laboratory" for housing. Since 2007, the Helsinki Living Lab has tested services and products in collaboration with the residents. In addition to the local information network, one important resident service is the housing association's own website, which is updated by a specific moderator from each association. 


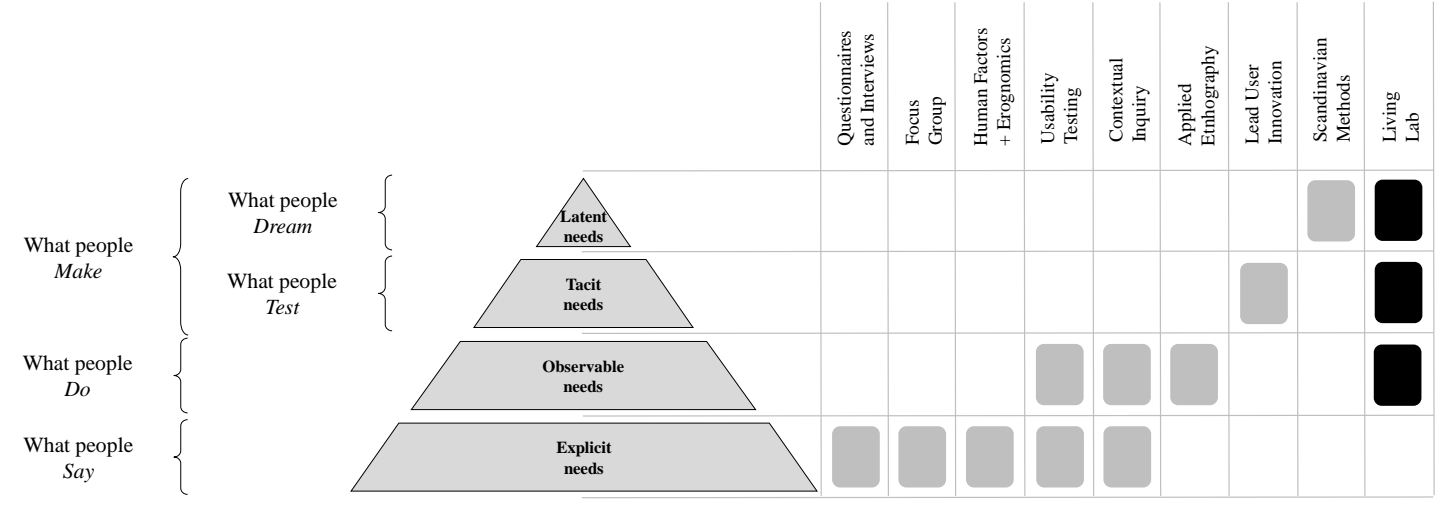

Figure 4: Users' needs explored by Living Lab methodology

\section{A model of different specifications of the Living Lab methodology}

In this section, we introduce a model of different forms of this methodology that represent different types of Living Labs. In our analyses, the wide variety of Living Lab typologies emerged as one main difficulty of the limited consolidation of the definitions and theories utilised by Living Labs. Thanks to the analyses of a the literature and of the case studies we identified a series of peculiarities of the Living lab methodology. The key shared characteristics (namely real-life experimentation environment and involvement of aware users in the co-creation) led to our definition. The other peculiarities are used in this paragraph to further characterize the different Living Lab methodologies and to propose a model to support the adoption of this methodology. In particular we identify two variables to help organise the complex phenomenon of the Living Labs: the type of interaction with the users (open or closed), on the one hand, and decisions regarding platform technology (value capturing or value creation), on the other. We selected these two variables that allow specification of the two most relevant peculiarities of the Living Lab methodology (i.e., user involvement and presence of artefacts). These variables allow us to identify four Living Lab methodological specifications that we have recognised as widely diffused and coherent with managers' choices. The second part of our study aimed to create further understanding of the phenomenon and support managers in the adoption of the Living Lab methodology.

The importance of these two variables is discussed below, while the positioning of the case studies in the matrix are detailed in Table 3.

\section{Interaction with users (Open vs Closed)}

The first variable that emerged from our analysis is related to the modality of user involvement. As previously shown, the involvement of aware users in the co-creation processes is a main peculiarity of this methodology. All Living Labs involve aware users in the co-creation process, but participation may be open to all potential users in some cases, while the users are pre-selected in other cases. As previously mentioned, Sanders (2002) identifies a shift in perspective occurring at the collaborative edge of design and social science. This shift moves from a user-centred design process to a design process centred upon participatory experiences. According to Pisano and Verganti (2008), collaborative architectures come in a wide variety of forms, and there is no single best collaborative architecture. These authors propose a model in which a critical choice is the degree to which a collaborative network is open or closed; collaborative networks differ in the degree to which "membership" is open to anyone who wants to join. Similarly, the Living Labs framework can foresee different modalities in the involvement of the final users, e.g., OPEN 
Living Labs imply that everyone has the right to participate. As discussed by Pisano and Verganti (2008), there are no rules dictating who can join and who cannot join OPEN Living Labs, and no one is vested with the authority to exclude someone. On the contrary, users in CLOSED Living Labs are pre-selected and consequently invited to participate.

Normally, closed strategies enable more focused and in-depth user feedback. Closed strategies additionally require the capacity to select users and limit access to the experience setting. Open strategies are simpler to implement and allow more diverse feedback but require the capacity to filter results and manage the greater number of users.

\section{Role of platform technology (Value Appropriation VS Value Creation)}

The second variable that emerged from our analysis concerns the role of the technology platform used in the Living Lab. All Living Labs rely on technology on which the main products or services are developed or experienced by users. Indeed, the presence of artefacts is one peculiarity of the Living Lab methodology. These infrastructures are primarily based on information and communication technologies (ICT) such as broadband or mobile infrastructures. The Living Lab is used to describe an experimental platform where the user is studied in his or her everyday habitat (Eriksson et al., 2005). The platform works as an ecosystem in which users are subjected to a combination of research methodologies while the Living Lab organisation tests new or existing technologies that are still in development. This process uses quantitative as well as qualitative research methods with the research focus on accessing user ideas and knowledge of the tested technology that is used within a Living Lab setting (Eriksson et al., 2005). These platform technologies may be standard infrastructures that have been previously tested and used outside the Living Lab or experimental, new technologies that are developed ad hoc for the specific Living Lab and the specific product or service being developed. In the Rener Living Lab (Portugal), ad hoc physical and ICT infrastructures, such as car stations and management software, were built for the mobile-car sharing service.

The different role of the platform technology may be understood in terms of the differences between value appropriation and value creation strategies, Value creating strategies are based on the exploration of opportunities generated by new technologies. These strategies can be linked to the resource-based theories that underscore the importance of developing unique, difficult to imitate strategic resources (e.g., Wernerfelt, 1984; Barney, 1991). Value appropriation strategies are based on exploiting the opportunities provided by existing technologies. Advocates of value appropriation strategies argue that the creation of strategic assets is not enough to obtain and maintain a competitive position in the market; strategies of value appropriation, such as the development of complementary assets, are pivotal to transform the strategic assets into effective results and maintain these results over time (Teece, 1986; Mizik and Jacobson, 2003). Both approaches can lead to significantly innovative results, but value appropriation strategies are more common due to lower required investments.

\begin{tabular}{|l|l|l|l|}
\hline$\#$ & Name & Interaction with users & Role of Platform technology \\
\hline 1 & $\begin{array}{l}\text { MOBILE CITY } \\
\text { BREGENZ, Austria }\end{array}$ & $\begin{array}{l}\text { OPEN: every citizen can access } \\
\text { the system because new services } \\
\text { are developed in the mobile city } \\
\text { platform. }\end{array}$ & $\begin{array}{l}\text { VALUE APPROPRIATION: } \\
\text { Mobilkom Austria, Mobile city } \\
\text { provider, offers all the ICT } \\
\text { infrastructure necessary for the } \\
\text { Living Lab. }\end{array}$ \\
\hline 2 & $\begin{array}{l}\text { VORALBERG, } \\
\text { Austria }\end{array}$ & $\begin{array}{l}\text { CLOSED: project-oriented } \\
\text { citizens are chosen. }\end{array}$ & $\begin{array}{l}\text { VALUE APPROPRIATION: the } \\
\text { industry and various providers } \\
\text { offer technological support to the } \\
\text { Living Lab. Access to this } \\
\text { technology is one value that can be }\end{array}$ \\
\hline
\end{tabular}




\begin{tabular}{|c|c|c|c|}
\hline & & & appropriated from the Living Lab. \\
\hline 3 & IBBT City, Belgium & $\begin{array}{l}\text { CLOSED: the correct user panel is } \\
\text { selected and recruited for each } \\
\text { project. }\end{array}$ & $\begin{array}{l}\text { VALUE APPROPRIATION: the } \\
\text { industry and various providers } \\
\text { offer technological support to the } \\
\text { Living Lab. Access to this } \\
\text { technology is one value that can be } \\
\text { appropriated from the Living Lab. }\end{array}$ \\
\hline 4 & $\begin{array}{l}\text { TURKU } \\
\text { ARCHIPELAGO, } \\
\text { Finland }\end{array}$ & $\begin{array}{l}\text { OPEN: there is an open } \\
\text { community that actively } \\
\text { participates in all projects enabled } \\
\text { by the new antennas. }\end{array}$ & $\begin{array}{l}\text { VALUE CREATION: the } \\
\text { infrastructure in the Turku } \\
\text { Archipelago is composed of the } \\
\text { installation of two new WiMax } \\
\text { antennas covering } 65 \% \text { of the } \\
\text { islands. }\end{array}$ \\
\hline 5 & $\begin{array}{l}\text { ARABIANRANTA, } \\
\text { Finland }\end{array}$ & $\begin{array}{l}\text { OPEN: resident citizens can } \\
\text { participate in the Living Lab as a } \\
\text { volunteer. }\end{array}$ & $\begin{array}{l}\text { VALUE APPROPRIATION: a } \\
\text { VPN (virtual private network) } \\
\text { provides all necessary services to } \\
\text { the different stakeholders, but the } \\
\text { VPN is hosted on an existing } \\
\text { platform. }\end{array}$ \\
\hline 6 & FRASCATI, Italy & $\begin{array}{l}\text { CLOSED: The citizens are only } \\
\text { included in the innovation process } \\
\text { if they achieve a sense of } \\
\text { belonging, motivation and } \\
\text { active continuous participation in } \\
\text { the activities of the KBS } \\
\text { (knowledge, business and social) } \\
\text { communities. }\end{array}$ & $\begin{array}{l}\text { VALUE CREATION: Currently, } \\
\text { the Frascati Living Lab is } \\
\text { primarily structured over a } \\
\text { development server that tests all } \\
\text { new services and functionalities } \\
\text { before definitive deployment using } \\
\text { new technologies. }\end{array}$ \\
\hline 7 & $\begin{array}{l}\text { MOBILE PASS, } \\
\text { Italy }\end{array}$ & $\begin{array}{l}\text { OPEN: every citizen (maximum } \\
\text { of } 100 \text { ) can access the service by } \\
\text { registering on the mobile pass } \\
\text { website. }\end{array}$ & $\begin{array}{l}\text { VALUE APPROPRIATION: } \\
\text { Mobile Pass is based on the } \\
\text { existing technological } \\
\text { infrastructure of the public } \\
\text { transportation company and } \\
\text { Telecom companies. }\end{array}$ \\
\hline 8 & $\begin{array}{l}\text { CASST CENTRE, } \\
\text { Ireland }\end{array}$ & $\begin{array}{l}\text { OPEN: every citizen can } \\
\text { participate in the services offered } \\
\text { by the Living Lab. }\end{array}$ & $\begin{array}{l}\text { VALUE APPROPRIATION: the } \\
\text { ICT infrastructure is offered by a } \\
\text { mobile operator and based on } \\
\text { different existing technologies. }\end{array}$ \\
\hline 9 & $\begin{array}{l}\text { KENNISWIJK, } \\
\text { Netherlands }\end{array}$ & $\begin{array}{l}\text { CLOSED: Rounds of users are } \\
\text { chosen to participate in } \\
\text { Kenniswijk, and certain } \\
\text { methodologies of choice are used } \\
\text { to select the appropriate group of } \\
\text { people. }\end{array}$ & $\begin{array}{l}\text { VALUE CREATION: The } \\
\text { channel's installation of broadband } \\
\text { with some incentives to citizens } \\
\text { and new services represent new } \\
\text { types of ICT infrastructure. }\end{array}$ \\
\hline 10 & RENER, Portugal & $\begin{array}{l}\text { OPEN: the Living Lab is } \\
\text { completely open to all citizens and } \\
\text { tourists that visit Rener. }\end{array}$ & $\begin{array}{l}\text { VALUE CREATION: ad hoc } \\
\text { physical and ICT infrastructures } \\
\text { for the mobile-car sharing service, } \\
\text { such as car stations and } \\
\text { management software. }\end{array}$ \\
\hline 11 & $\begin{array}{l}\text { CANTABRIA, } \\
\text { Spain }\end{array}$ & $\begin{array}{l}\text { OPEN: the use is promoted by the } \\
\text { regional government and town } \\
\text { hall by placing web page tools for } \\
\text { citizen use. }\end{array}$ & $\begin{array}{l}\text { VALUE CREATION: The Living } \\
\text { Lab is oriented to the creation of } \\
\text { ICT infrastructure (mobile } \\
\text { technologies and broadband, not } \\
\text { physical infrastructure). }\end{array}$ \\
\hline 12 & $\begin{array}{l}\text { CUDILLERO, } \\
\text { Spain }\end{array}$ & $\begin{array}{l}\text { CLOSED: users are selected and } \\
\text { recruited from the organisers of } \\
\text { the Living Lab. }\end{array}$ & $\begin{array}{l}\text { VALUE APPROPRIATION: an } \\
\text { existing infrastructure contains all } \\
\text { services proposed by the users. }\end{array}$ \\
\hline 13 & I2CAT, Spain & $\begin{array}{l}\text { OPEN: every citizen can use the } \\
\text { Living Lab to participate in almost }\end{array}$ & $\begin{array}{l}\text { VALUE CREATION: an extensive } \\
\text { fibre Internet } 2 \text { network, media and }\end{array}$ \\
\hline
\end{tabular}




\begin{tabular}{|c|l|l|l|}
\hline & $\begin{array}{l}\text { every project by simply } \\
\text { subscribing to the Living Lab } \\
\text { website. }\end{array}$ & $\begin{array}{l}\text { UMTS - Wifi network connects } \\
\text { universities and media companies, } \\
\text { and i2Cat uses the network for } \\
\text { activities and projects. }\end{array}$ \\
\hline 14 & $\begin{array}{l}\text { TESTBED } \\
\text { BOTNIA, Sweden }\end{array}$ & $\begin{array}{l}\text { CLOSED: citizens are specifically } \\
\text { recruited for each project. Some } \\
\text { criteria are used to determine the } \\
\text { citizens. }\end{array}$ & $\begin{array}{l}\text { VALUE APPROPRIATION: the } \\
\text { existing ICT infrastructure (3G, } \\
\text { WiMax) is offered in cooperation } \\
\text { with owners and the university. }\end{array}$ \\
\hline
\end{tabular}

Table 3: Positioning of the Living Labs

The intersection of the two variables previously described gives rise to four possible Living Lab methodological specifications in which the analysed case studies are positioned (Figure 5). It is useful to underline that the methodology and thus the tools and the main activities of the designers remain very similar because these four possibilities are only specifications of the same methodology (i.e. the Living Lab methodology). However the four specifications introduce some differences that are useful to tailor the methodology in particular to different phases of the innovation process.

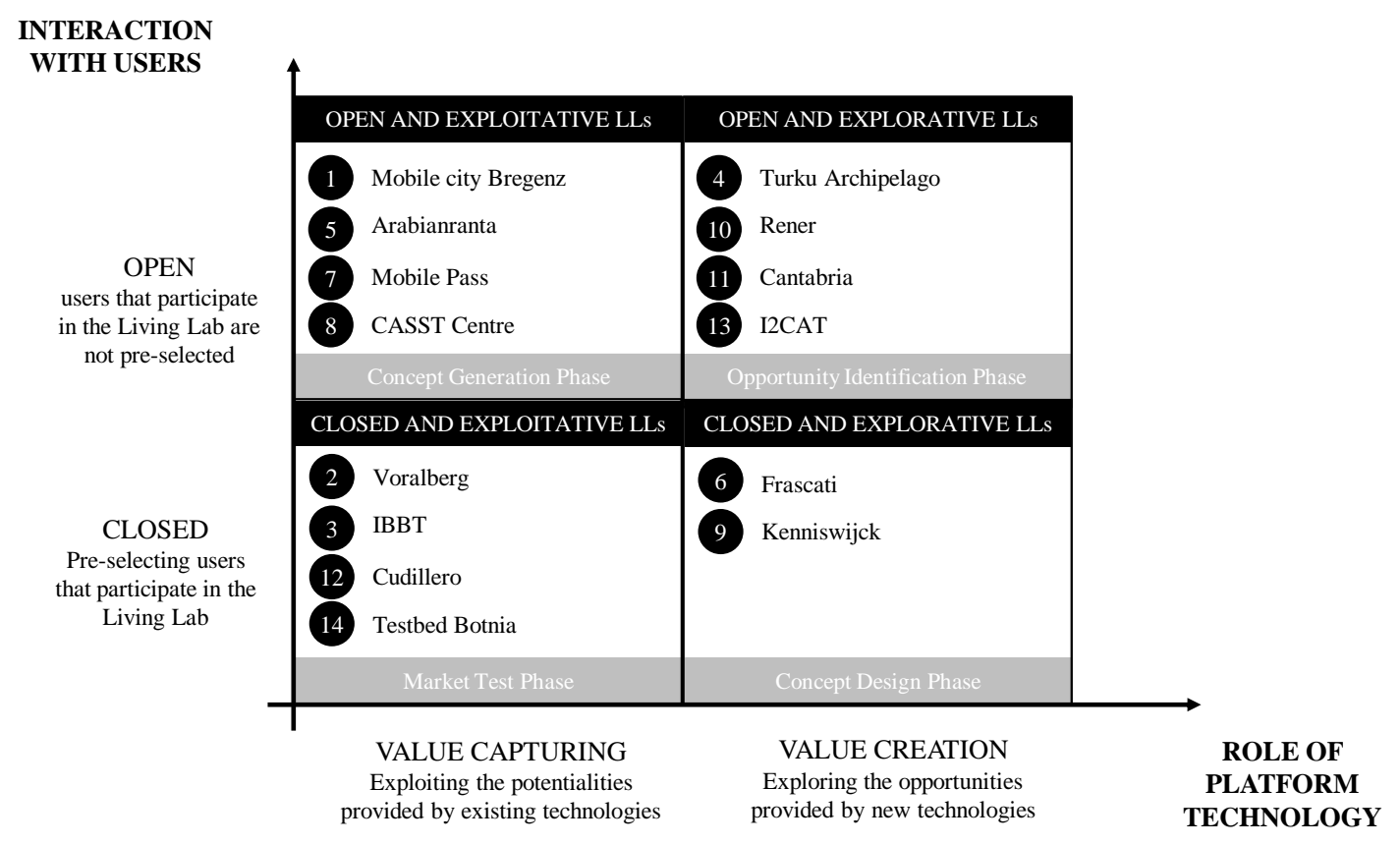

Figure 5: Specifications of the Living Lab methodology including the positioning of the case studies and the more common development stages

The upper right quadrant (Open and Explorative Living Labs) represents the Living Lab methodological configuration most suited for the "opportunity identification" phase (see Crawford and Di Benedetto, 2010). In this configuration, new tools and technologies are introduced to a diverse and unfiltered set of users that can provide feedback, suggestions and development contributions. In the upper left quadrant (Open and Exploitative Living Labs) the level of involvement is similar, but the tools and products are based on already existing technologies and thus are related to the "Concept Generation" phase. In both cases, the 
challenge for the designers remains in the ability to filter the results and manage the greater number of users. The bottom right quadrant (Closed and Explorative Living Labs) represents the Living Lab methodological configuration most suited when there are methodological specifications based on the pre-selection of users allowed to participate. This choice is normally related to the subsequent phase of the innovation process, i.e. the "Concept Design" phase. A more developed product or service with clear characteristics permits a more limited but focused set of feedbacks and suggestions. This choice reduces the potential for new and unexpected contributions (creativity) and requires higher costs to select the users and limit access to the experience setting. The lower left quadrant (Closed and Exploitative Living Labs) is the methodological specification more suited for the "Market Test" phase. The lower right quadrant is suited for new technologies and tools that require testing from ad hoc users based on level of development or specific characteristics precluding the involvement of general users.

\section{CONCLUSIONS}

The potentials of user-centred and participatory design approaches have been widely acknowledged (Veryzer and Borja de Mozota, 2005), but limited attention has been devoted to the Living Lab methodology. Despite the diffusion of these organisations and recent interest from scholars and policy makers, no detailed Living Labs analysis has considered the methodology's characteristics and potentials. We adopted an empirical but theory-driven approach based on 14 cases that use the Living Labs methodology to highlight the shared characteristics and peculiarities and propose a possible definition. We underlined the cocreative potential, highlighted user awareness and real life settings and evidenced differences with other design research methodologies. Specifically, we emphasised that i) Living Lab methodology can be applied to investigate a broad variety of user needs (observable, tacit and latent) and consolidate design research methodologies that focus on specific categories of user needs and ii) this methodology leverages context as an important element of the design process allowing the users to interact with the new products and services in their daily lives. From a managerial perspective, these peculiarities allow new design processes and design results that are yet to be fully explored and understood. The methodology additionally requires designers the development of new competences. Designers that apply the Living Lab methodology have to facilitate and lead co-creation processes based on contextual factors and enrich their stakeholder interaction capabilities and interpretative capabilities to assess local settings.

Our case based research allowed identification of four different Living Labs specifications that consider open user involvement and the type of technological platform adoption. Consequently, the Living Lab methodology can be applied to exploit the potentialities of existing technologies or to explore the opportunities provided by new technologies. The methodology can pre-select the involved users, identify the knowledge domain to address or leverage the serendipity value of unknown users.

Despite the contribution, we acknowledge the limitations of our work. First, we did not explore all differences and variables that potentially characterise different Living Labs. For instance, we did not analyse the differences in temporary or permanent organisations, different shareholders, different financial sources or policy maker roles. Second, data availability and European phenomenon diffusion only permitted consideration of European cases in this study. Further analysis of other geographical area might be interesting to further generalise our results. Furthermore, we only considered a methodological perspective in our analysis of the Living Labs; other analyses from an organisational or institutional perspective could usefully complement our work. Finally, further analyses are required to understand the 
best performing Living Labs, the most effective management types and the firms that would most benefit from this methodology.

\section{REFERENCES}

- Ball LJ and Ormerod TC (2000). Putting ethnography to work: the case for a cognitive ethnography of design. International Journal Human-Computer Studies, Vol. 53, 147168.

- Ballon, P., Pierson, J. and S. Delaere (2005) Open Innovation Platforms for Broadband Services: Benchmarking European Practices. Proceedings of 16th European Regional Conference, Porto, Portugal, September 4-6, 2005

- Barney J (1991). Firm Resources and Sustained Competitive Advantage. Journal of Management, Vol. 17, No. 1, Pp. 99-120.

- Bergvall-Kåreborn, Eriksson, Ståhlbröst, Svensson (2009) A Milieu for Innovation Defining Living Labs

- Burns A, Barrett R, Evans S and Johansson C (1999). Delighting consumers through empathic design. Proceedings of the 6th International Product Development Management Conference. Cambridge, UK.

- Crawford M and Di Benedetto A (2010). New Products Management. McGraw-Hill (10 ed), 2010.

- Dahan E and Hauser JR (2001). Product development managing a dispersed process. In Handbook of Marketing. 2001.

- Dahan E and Hauser JR (2002). The virtual consumer. Journal of Product Innovation Management, Vol. 19, Pp. 332-353.

- Dell'Era C (2011). LANGUAGE MINING: managing design drive innovation by capturing, interpreting and communicating knowledge about socio-cultural trends. Lambert Academic Publishing.

- Eisenhardt, K.M. and Graebner, M.E. (2007) Theory building from cases: opportunities and challenges. Academy of Management Journal, 50, 1, 25-32.

- Eriksson, M., V. P. Niitamo, and S. Kulkki. (2005). State-of-the-Art in Utilizing Living Labs Approach to User-centric ICT innovation - a European approach

- Feurstein, K., K. A Hesmer, K-D Hribernik, and J. Schumacher. Living Labs: A New Development Strategy. In European Living Labs - A new approach for human centric regional innovation, Eds. J. Schumacher \& V-P Niitamo. Berlin: Wissenschaftlicher Verlag Berlin, 2008, pp. 1-14

- Frissen V and van Lieshout M (2004). To user-centred innovation processes: the role of living labs. Delft, TNO-ICT.

- Greenbaum, J., and Kyng, M. (1991). Design at work: Cooperative design of computer systems. Hillsdale NJ: Erlbaum

- Kallai (2010) State-of-the-art in utilizing Living Labs approach to user-centric ICT innovation

- Kelley T (2001). The Art of Innovation. New York: Curreny.

- Konsti-Laasko S., Pihkala T and Kraus S (2012). Facilitating SME Innovation Capability through Business Networking. Creativity and Innovation Management, Vol. 21, No. 1, Pp. 93-105.

- Kotler P and Scott WG (1999). Marketing Management. Prentice Hall International, 7a ed.

- Kumar V and Whitney P (2003). Faster, Deeper User Research. Design Management Journal, Vol. 14, No. 2, Pp. 50-55. 
- Kviselius NZ and Andersson P (2009). Living labs as tools for open innovation. Communications \& Strategies, Vol. 74, Pp. 75.

- Living Lab Handbook (2010) www.ve-forum.org/apps/comm.asp? \$1=528

- Lojacono G and Zaccai G (2004). The evolution of the Design-Inspired Enterprise. Sloan Management Review, Spring, 75-79.

- Maslow A (1974). Motivazione e personalità. Armando Editore, Roma.

- Miles, M.B. and Huberman, A.M. (1994), Qualitative Data Analysis: an expanded sourcebook, Sage, Thousand Oaks, CA.

- Mizik, N. e Jacobson, R. 2003. Trading Off Between Value Creation and Value Appropriation: The Financial Implications of Shifts in Strategic Emphasis. Journal of Marketing 67: pp. 63-76.

- Muller, M.J., and Kuhn, S. (Eds.) (1993). Communications of the ACM special issue on participatory design, 36(6), June 1993

- Patnaik D and Becker R (1999). Needfinding: The Way and How of Uncovering People's Needs. Design Management Journal, No. 2, Pp. 37-43.

- Pisano G and Verganti R (2008). Which Kind of Collaboration is Right for You? Harvard Business Review.

- Prahalad C.K. and Ramaswamy, V. (2004). Co-creation experiences: the next practice in value creation. Journal of interactive marketing, 18 (3), 5-14.

- Rosenthal SR and Capper M (2006 ). Ethnographies in the Front End: Designing for enhanced Customer Experiences. Journal of Product Innovation Management, Vol. 23, No. 3, Pp. 215-237.

- Roveda C., Vecchiato R., Verganti R., \& Landoni P. (2007). A new methodology for regional foresight. International Journal of Foresight and Innovation Policy, 3(2), 218-234

- Sanders EB (1992). Converging perspectives: Product development research for the 1990s. Design Management Journal, Pp. 49-54.

- Sanders EB (2001). Virtuosos of the experience domain. In 2001 IDSA Education Conference.

- Sanders EB (2002). From user-centered to participatory design approaches. Design and the Social Sciences.

- Sanders EB (2006). Design research in 2006. Design Research Quarterly 1, No. 1, Design Research Society, September 2006.

- Sawhney, M, Prandelli E and Verona G (2003). The Power of Innomediation. MIT Sloan Management Review, Vol. 44, No. 2.

- Schuler, D., and Namioka, A. (1993) (Eds.). Participatory design: Principles and practices. Hillsdale NJ USA: Erlbaum

- Schuurman D, Lievens B, De Marez L and Ballon P (2012). Towards optimal user involvement in innovation processes: a panel-centered living lab-approach. Technology Management for Emerging Technologies (PICMET), 2012 Proceedings of PICMET'12: (pp. 2046-2054). IEEE.

- Spradley JP (1979). The ethnographic interview. Harcourt Brace Jovanovich College Publishers, Orlando, FL.

- Ståhlbröst A and Bergvall-Kåreborn B (2008). FormIT - an Approach to User Involvement. European Living Labs - A new approach for human centric regional innovation. Berlin, WVB: 64-75.

- Sleeswijk Visser, F., Stappers, P.J., van der Lugt, R., and Sanders, E.B.-N., 2005. Contextmapping: experiences from practice. CoDesign, 1 (2), 119-149.

- Sutton RI (2001). The weird rules of creativity. Harvard Business Review, September, Pp. 95-103. 
- Tang T, Wu Z, Hamalainen M and Ji Y (2012). From Web 2.0 to Living Lab: an Exploration of the Evolved Innovation Principles. Journal of Emerging Technologies in Web Intelligence, Vol. 4, No. 4, Pp. 379-385.

- Teece D.J., 1986. Profiting From Technological Innovation: Implications For Integration, Collaboration, Licensing And Public Policy. Research Policy 15: pp.285-305.

- Thomke S and Nimgade A (1999). Note on Lead User Innovation. Harvard Business School.

- Tseng M.M. and Piller F.T. (2003). The customer centric enterprise: advances in mass customization and personalization. Berlin: Springer.

- Verganti R (2001). Le nuove sfide per l'innovazione di prodotti e servizi. Proceedings of Riunione Scientifica AiIG.

- Wernerfelt B (1984). A Resource-Based view of the Firm. Strategic Management Journal; Vol. 5, No. 2, Pp. 171-180.

- Veryzer RW and Borja de Mozota B (2005). The Impact of User-Oriented Design on New Product Development: An Examination of Fundamental Relationships. Journal of Product Innovation Management, 22:128-143.

- Von Hippel E (1986). Lead Users: A source of novel product concepts. Management Science, Vol. 32, No. 7, Pp. 791.

- Von Hippel E (2001). PERSPECTIVE: User toolkits for innovation. Journal of Product Innovation Management, Vol. 18, 247-257.

- Von Hippel E (2005). Democratized Innovation, Cambridge, MA: The MIT Press.

- Vredenburg K, Scott I and Righi C (2002). User-Centered Design: An Integrated Approach. Upper Saddle River, NJ: Prentice Hall PTR.

- Yin, R.K. (1984) Case Study Research, Design and Methods. London: Sage Publications. 